\title{
The Strategy of 'Scale' in Policy- Making Process: A Case Study of Eco-Town Project, Kitakyushu City
}

\section{YIN Guanwen}

College of Population, Resources and Environment, Shandong Normal University; Jinan 250014, China.

E-mail:yingw2012@126.com

Received January 31, 2014; Accepted June 4, 2014

\begin{abstract}
Efforts to implement sustainability-oriented policies through environmental governance have become increasingly critical across the globe, during the past 20 years. This article analyzes the policy-making process of an Eco-Town project, a support policy for the development of the recycling industry in Japan, based on a case study in Kitakyushu City. Contrary to the majority of literature on Eco-Towns, which primarily examines economic factors, this article aims to illustrate the struggles, negotiations, and collaboration necessary between the local government and actors at different scales. In order to implement a recycling scheme in the post-steel era, the Kitakyushu City Government coordinated with various actors through the strategy of scale. The local government initiated a local recycling scheme to address global environmental issues and to persuade other actors to change their attitudes. The local government contacted national actors to seek support and stretch its influence. Similarly, facing protests by citizens and civic organizations, it emphasized environmental issues on a global scale in order to legitimize its claims and seek understanding. Furthermore, it cooperated with actors in other countries to continue to stretch its influence on a transnational scale. As a result, consensus was established and a cooperative relationship emerged among the actors participating in the policy-making process. The recycling scheme was then successfully implemented as an Eco-Town project, and the Eco-Town concept spread to the transnational scale indicating that the strategy of scale is useful in the policy-making process and in expanding the influence of the policy.
\end{abstract}

Key words policy-making process, politics of scale, Eco-Town project, Kitakyushu City

\section{Introduction}

Along with the 1992 Rio Summit and its major outcomes, environmental governance efforts to implement sustainability-oriented policies have become increasingly critical over the past 20 years across the globe. Japan has also endeavored to construct a recycling-oriented society and has taken up a vast array of initiatives such as the Containers and Packaging Recycling Law and the Home Appliance Recycling Law which were enacted in the 1990s. One of the most significant efforts toward sustainability occurred in 1997, when an Eco-Town project was established by the Ministry of International Trade and Industry (MITI) $)^{1}$. As a support institution for urban environmental development, especially the recycling industry, there have been 26 Eco-Towns constructed in Japan since 2012.

The Eco-Town Project has been documented extensively in the literature. However, a major concern is that the development process is strictly described through the analysis of economic factors. For instance, there is widespread concern about the centralization of the recycling industry into Eco-Town projects. Local government intervention, through the construction of support facilities, the provision of testing materials and briefings for residents, is believed to be the essential factor in promoting the industrial agglomeration in the Eco-Town of Kitakyushu City ${ }^{2}$ (Togawa 2001). In addition, cooperation among research organizations and enterprises and the support policies for small and medium sized enterprises are also significant (Matsunaga 2004).

In contrast, Eco-Town of Omuta City has no clear plan to develop the recycling industry other than to construct a refuse derived fuel (RDF) power generation, which is considered the main reason for its slow industrial agglomeration process (Togawa 2000). Moreover, taking Kitakyushu City as the case study, Okamura (2004) explores the advantages and disadvantages of automotive recycling industries located in Eco-Towns.

The role of the Eco-Town in creating a recycling-oriented society has been examined by scholars who focus their research on the method of integrating the development of the recycling industry into regional development. Nakamura (2001) analyzes the recycling industries in Kitakyushu Eco-Town and Kawasaki Eco-Town and concludes that the agglomeration of the recycling industry alone cannot create a sustainable society, but must be considered along with ways of reducing resource in- 
puts. Similarly, according to an investigation of Kawasaki Eco-Town (Samuta 2003), the recycling industry's development has not led to environmental improvement. In fact, it has caused deterioration in air quality due to an increase in the transportation of raw materials and products.

More recently, research focusing on the behavior and action of the actors in the Eco-Town development process has been emerging. Interviews with the local government, citizens, and firms located in Omuta Eco-Town suggest that there is a significant lack of communication between the citizens and the local government as well as between the citizens and local corporations, creating an obstacle for the Omuta Eco-Town project (Yamamoto et al. 2006).

As noted above, although there is research focusing on the behavior and action of the actors, current literature on Eco-Town projects mainly focuses on economic factors. However, even as a significant policy in environmental governance, the political process of the Eco-Town project is yet to be examined. The importance of "extraeconomic" factors, such as actors, practices, and politics in the study of Eco-Town projects, needs to be acknowledged. Consequently, this article places more emphasis on analyzing the policy-making process of Eco-Town projects. In particular, concentrating on the case study of Kitakyushu City, this article aims to illustrate the struggle, negotiations and collaboration necessary between the local government and other actors involved in the EcoTown project through the lens of "politics of scale."

The rest of this article will be organized as follows. The second section introduces the methodology and data used in this research. The third section gives a brief review of Kitakyushu City. The following three sections contain the main ideas of this article, providing an explanation of the policy-making process of Kitakyushu Eco-Town project, and an elaboration of the abandoned recycling industry, the birth of the Eco-Town project and its implementation, and its spread to a transnational scale. Last, the main conclusions of the article are re-examined and several theoretical implications are summarized.

\section{Politics of Scale}

The theory of politics of scale will be applied to this study in order to clarify the political process of the Kitakyushu City Eco-Town project. Over the last few decades, the examination of the interaction and relationships between different interest groups involved in urban governance, has become one of the most dominant paradigms of thought in the literature on urban politics. However, criticism that these studies fail to take scale into account has been emerging. In many cases, urban planning is seen as a process of cooperation between local governments, businesses, and civic organizations.

Due to this oversight in the literature, scholars tend to consider the "politics of scale" (Tretter 2008) which focuses on how urban politics utilize different networks of scales and the relationship that exists between these scales. This term refers to the ways in which social actors draw on relationships at different geographical scales to seek an advantage in a given political situation (Martin et al. 2003). Not all actors necessarily agree about the scale at which a particular political project should take place, and therefore the actors must begin collaboration, negotiation, and exchange which comes along with contestation and struggle (Smith and Kurtz 2003).

"Jumping scale" is a tactic used by actors at a certain scale in order to gain legitimacy beyond their given scale (Smith 1992). Local actors often engage in events, conditions, and processes operating well beyond the local scale in order to maintain well-being in today's globalized world. Local actors establish contact with actors from other scales for various reasons: to find new allies for cooperation; to escape competition or control, to stretch their spatial reach of influence, to legitimize certain political-economic claims, and, to mobilize a new collective political actor (Swyngedouw 1997; Bayirbag 2010).

Thus, the concept of "scale" has been associated with political activities, through which political actors may realize competitive advantages. The "politics of scale" offers an approach through which the policy-making process of Kitakyushu City Eco-Town can be examined. However, most of the literature focuses on the marginal groups who take advantage of "scale" to protect their political claims and interests in urban redevelopment, environmental governance, or social movements (Brown and Purcell 2005; Merk 2009; Molle and Mamanpoush 2012; Yamazaki et al. 2012; Lai 2013). Kitakyushu City's local government, however, used strategy as a way to implement the Eco-Town project. Using the strategy of "scale," the local government reached a consensus among multiple actors and expanded the Eco-Town concept from the local to the national scale, and even to the transnational scale.

To examine local government strategies of "scale," this study will focus on the following issues: (1) the position of each political actor at local and extra-local scales; (2) how they struggle, negotiate, and collaborate with each other in the policy-making process; (3) and through what paths the Eco-Town concept shifts from the local scale to extra-local scales? 


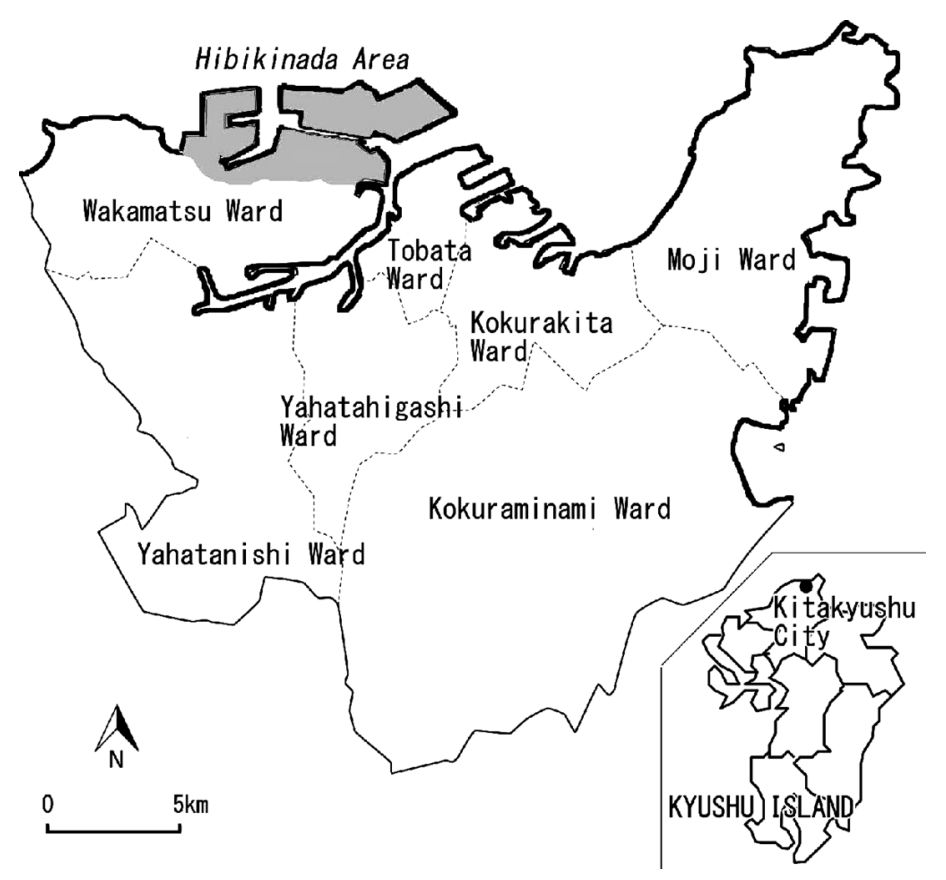

Figure 1. Kitakyushu City and Hibikinada Area.

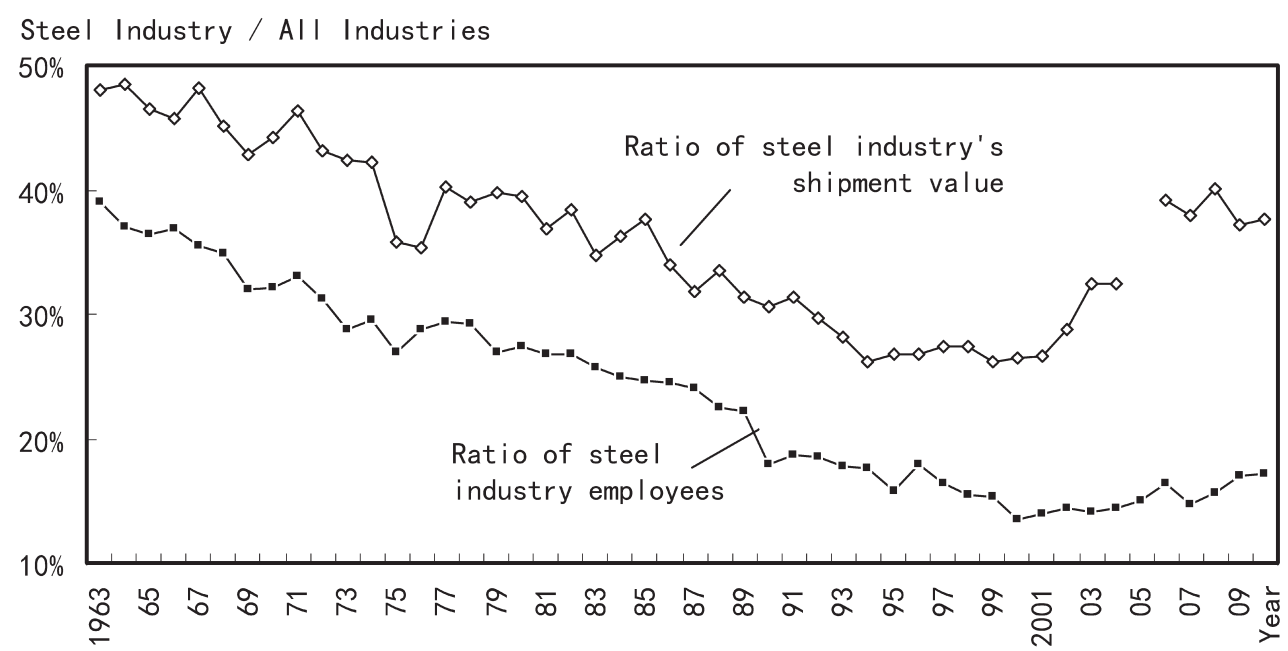

Figure 2. The depression in the steel industry of Kitakyushu City.

Note: Data of steel industry's shipment value in 2005 is absent.

Source: Kitakyushu City Government 2011.

The data used in this study mainly comes from interviews and fieldwork from April to July 2013. Semistructured interviews were carried out with Kitakyushu municipal officials, who took charge of the Eco-Town project, and experts involved in the policy-making process of the Eco-Town project and in research of the recycling industry. Statistical data, government documents, newspapers, and local historical materials were also collected and utilized in this study.

\section{Kitakyushu City: Its Post-Steel Transition}

Kitakyushu City is located in the northern part of Ky- ushu Island, and was established by the merger of five cities, Kokura, Moji, Yahata, Tobata, and Wakamatsu ${ }^{3}$, in 1963. Kitakyushu Eco-Town is located in the Hibikinada Area of the Wakamatsu Ward (Figure 1).

Historical representations of Kitakyushu City are nearly synonymous with the industrial history of Japan and images of plants smelting steel, producing chemicals, and building ships. The prosperity of Kitakyushu City was heavily dependent on the steel industry and the Nippon Steel Corporation (NSC) ${ }^{4}$.

However, along with an increase in demand for steel in metropolitan areas and the construction of the ironworks in the surrounding metropolitan areas, a portion 


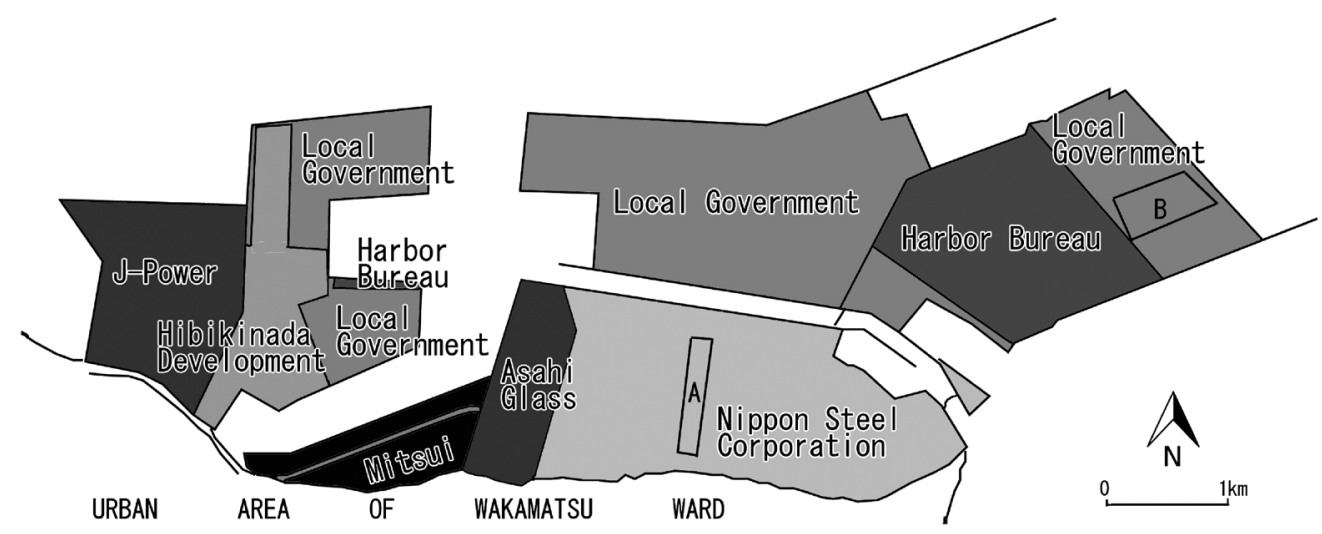

Figure 3. The land owners of Hibikinada Area.

Note: "A" denotes the practical research zone of the Eco-Town. "B" denotes the industrial complex zone of the Eco-Town. Source: Hibikinada Area Development Promotion Council 2003.

of businesses and employers began to move out of Kitakyushu City from the 1960s. Furthermore, the influence of the Oil Crisis in the 1970s drove Japan from an era of prosperity into an era of low growth. In particular, heavy industries such as ship building, iron and steel, and petrochemicals, experienced a recession. Consequently, since the 1960s, the ratio of the steel industry's shipment value and the ratio of steel industry employees have declined, ultimately causing a slump in the steel industry in Kitakyushu City (Figure 2).

On the other hand, Kitakyushu City also earned an ignominious reputation between the 1950s and 1960s as a place of suffering from environment pollution caused by industrial development. Although the local government and enterprises have been working together to address the pollution problem, concerns about environmental conditions of the city continue to be expressed (Editing Group of Pollution Control History 1998).

Within the context of the heavy industry depression and a greater awareness of environmental issues, the development of the Hibikinada Area was examined in the late 1980s. The Hibikinada Area is a landfill of 2,000 ha which was dumped by heavy industry enterprises such as the Nippon Steel Corporation (NSC) and the Mitsubishi Chemical Corporation. In addition, the local government and Kitakyushu Harbor Bureau own a large portion of land within this area (Kyushu Economic Research Center 2003) (Figure 3). When the landfill initially opened, the enterprises, such as the NSC and Mitsubishi Corporation, planned to expand their heavy industries into this area, but because of the economic decline of heavy industry, as noted above, the land owners and the local government decided to explore a new direction for land use and industry development. This point in the decision-making process marked the "inception" of the Eco-town project in Kitakyushu City.

\section{The Abandoned Recycling Industry Scheme}

To examine the development plan of the Hibikinada Area, the local government invited a professor of Kyushu University ${ }^{5}$, famous for stressing the importance of the recycling industry, to set up the Hibikinada Area Development Plan Committee in 1989 (Table 1). The committee was composed of local academic experts, officials from the local government, land owners, and civic organizations. A research group was funded by the NSC to investigate the industrial development of the Hibikinada Area (Hibikinada Area Development Plan Committee 1992).

Considering that the Hibikinada Area hosts a final disposal site, and that many enterprises possess high technical capabilities, the experts and research group proposed a recycling scheme in the Hibikinada Area. This scheme, however, was strongly opposed by one of the local civic organizations. This specific organization was concerned that the development of a recycling industry would bring a large amount of rubbish, and might cause local residents to protest. Also, the recycling industry was thought to be synonymous with the waste disposal industry, which could seriously damage the region's reputation. Thus, it was believed that recycling was not beneficial to local development when compared to its associated social and environmental costs (Hibikinada Area Development Plan Committee 1992).

In addition to this setback, there were several risks involved in developing the recycling industry at that time. For instance, the profitability of recycling was uncertain, and the legal system was incomplete. Therefore, both enterprises and the local government believed further investigation would be required to determine whether or not to initiate a recycling scheme. Consequently, the development of a recycling industry was ahead of its time, 
Table 1. Committees and seminars related to the Eco-Town project

\begin{tabular}{|c|c|c|c|}
\hline Period & Committee or Seminar & Member & Plan \\
\hline $1989 \sim 92$ & $\begin{array}{l}\text { Hibikinada Area Development Plan } \\
\text { Committee }\end{array}$ & $\begin{array}{l}\text { Local government, Harbor bureau, Land } \\
\text { owners, Experts, Civic Organizations }\end{array}$ & To develop recycling industry \\
\hline $1994 \sim 96$ & $\begin{array}{l}\text { Hibikinada Area Development Promotion } \\
\text { Committee }\end{array}$ & $\begin{array}{l}\text { Local government, Harbor bureau, Land } \\
\text { owners, Experts, Civic Organizations }\end{array}$ & To develop environmental industry \\
\hline $\begin{array}{l}1994 \\
\text { Nov. }\end{array}$ & Private Seminar & NSC, Mitsui & Concern about recycling industry \\
\hline $\begin{array}{l}1995 \\
\text { Mar. }\end{array}$ & Seminar on Environment Issues & Local government, NSC & $\begin{array}{c}\text { Establishment of a new company for PET } \\
\text { bottle recycling }\end{array}$ \\
\hline $\begin{array}{l}1995 \\
\text { Aug. }\end{array}$ & Seminar on Recycling Industry & Local government, NSC, Toshiba & $\begin{array}{c}3 \text { types of recycling industry } \\
\text { development }\end{array}$ \\
\hline $\begin{array}{l}1996 \\
\text { Jun. }\end{array}$ & Seminar on Environmental Industry & Local government & $\begin{array}{l}\text { Measures to promote environmental } \\
\text { industry }\end{array}$ \\
\hline 1997 & $\begin{array}{l}\text { Kitakyushu Environmental Industry } \\
\text { Promotion Committee }\end{array}$ & Local government, Land owners, Experts & $\begin{array}{l}\text { Implementation plan for Eco-Town } \\
\text { project }\end{array}$ \\
\hline
\end{tabular}

Source: See note 6 .

as recognized by the local government which concluded that, "the recycling industry is still early," and the scheme was abandoned in $1992^{6}$.

To summarize, the actors most involved in the policymaking process in the beginning phases were those at the local scale. Although experts had proposed a recycling scheme, the effort was opposed by a local civic organization and the stance of local businesses remained uncertain. The local government did not coordinate the effort effectively or propose solutions to the disagreements, but instead decided to shelve the plan passively.

\section{The Birth of the Eco-Town Project}

\section{From recycling industry to environmental industry}

While the recycling industry scheme was shelved, the mayor and NSC reorganized the Hibikinada Area Development Promotion Committee in 1994 (Table 1). During this period, the research group continued to investigate the possibility of developing the recycling industry in the Hibikinada Area. Also, both officials from the local government and enterprises, represented by the NSC, began to research recycling schemes through a series of seminars. Eventually, the government recognized that the recycling industry could help solve employment problems, and the NSC realized the economic potential of the recycling industry (Hibikinada Area Development Promotion Committee 1996). In 1996, a master plan to develop an environmental industry was determined, and the Kitakyushu Environmental Industry Promotion Committee was set up to discuss implementation of the Eco-Town project as a way to develop this industry.

Now we address the path through which the actors made the agreement and how a socially "unpleasant" scheme to develop a recycling industry turned into the preferred plan to develop the environmental industry. Using the strategy of "scale," the local government realized the value of transforming the recycling industry into the environmental industry. For this purpose, the local government connected a recycling scheme to environmental issues on a national and global scale. Since the Rio Summit in 1992, environmental issues have been addressed as an issue on a global scale. Discussion about "sustainable development" and "resource-recycling society" also took place in Japan. The recycling industry attracted the attention of the central government and relevant laws were enacted as a result. For the purpose of progressing in a rapidly changing global society, the government of Kitakyushu City made a plan to develop the environmental industry. In order to seek national funding, the local government began to contact the MITI, and exchange information on the recycling industry ${ }^{7}$. After that, an institution which supports the Eco-Town project was formed by the MITI, and Kitakyushu City was appointed as one of the first cities to receive subsidies in 1997. Through contact with actors at the extra-local scale, the local government legitimized its political-economic claims to develop an environmental industry.

At this phase, the local government used the strategy of scale to coordinate actors and gain a local consensus to develop the environmental industry. Through associating the industry's development with global environmental issues, the local government and enterprises recognized the possibility of and potential in the environmental industry. Through contacting the MITI, the local government persuaded an actor at the national scale to participate in 
the local policy-making process. Consequently, the environmental plan at the local scale became an Eco-Town project at the national scale. In other words, the plan of developing the environmental industry "jumped" from the local to the national scale.

\section{Government-business cooperation}

The local government cooperated with enterprises to promote implementation of the Eco-Town project. For instance, the local government established a cooperative relationship with the NSC to transfer land and construct infrastructure. The Eco-Town project was constructed on the NSC's land which consisted of a practical research zone (Figure 3, Area "A") and an industrial complex zone (Figure 3, Area "B").

As for the infrastructure construction, both the local government and the NSC thought that the other one should take charge. Considering that it would take a long time for the government to make budget decisions, the local government argued that it would be faster if the NSC built the infrastructure. The government made a proposal that the local government would purchase the land and that the NSC would build the infrastructure. In order to sell the land quickly, the NSC undertook infrastructure construction and the local government helped to apply for subsidies from the central government (Kitakyushu City Association 2003).

The local government and the NSC also cooperated to attract enterprises to construct companies in Eco-Town. In order to encourage research institutes to locate in the practical research zone, the NSC provided land free of charge to Fukuoka University's ${ }^{8}$ research institute. In addition, the NSC provided land for the automobile dismantling industry, which was considered an industry with a poor reputation among most landowners in the Hibikinada Area. Furthermore, the NSC contributed to the development of the recycling industry by establishing new companies ${ }^{9}$ (Kitakyushu City Association 2003). Accordingly, the local government assisted the NSC in creat- ing its new business in the Eco-Town. For instance, the local government helped the NSC's new company collect raw materials and sell products.

The local government also supported enterprises in the Eco-Town through various measures. In order to support small and medium-sized enterprises, the government purchased $3 / 4$ of the land in the industrial complex zone from the NSC, and leased it to enterprises that had difficulty purchasing land. Compared with the cost of purchasing land, at $25,900 \mathrm{yen} / \mathrm{m}^{2}$, the price of leasing land is just 33yen $/ \mathrm{m}^{2} /$ month $^{10}$, which significantly reduced the financial burden for small and medium sized enterprises (Table 2). Similarly, in order to support research institutes, the local government purchased half of the land of the practical research zone, and leased the land at a price of 40 yen $/ \mathrm{m}^{2} /$ month.

In addition, the local government promoted enterprise establishment through holding seminars on the recycling industry. For instance, in order to attract Kitakyushu ELV Cooperative Association ${ }^{11}$, the government held a series of 300 seminars with relevant enterprises in a two year time frame. Also, the local government supported enterprises by ensuring subsidies and financing from financial institutions. Furthermore, the local government took advantage of its relationship with public organizations and enterprises to promote further establishment of enterprises. For instance, both Fukuoka Prefecture and the NSC set up a research institute in the Eco-Town at the request of the Kitakyushu City Government ${ }^{12}$.

Through cooperation between the local government and companies, the number of companies in the EcoTown has reached a total of 29, creating over 1,000 jobs (Figure 4). With local government support of land, finance, information, and services, the number of companies increased dramatically from 1998 to 2003, rising from one to 21. The majority of the companies were established by enterprises located in Kitakyushu City and three of them were companies related to the NSC. In the period from 2004 to 2012, the NSC established two

Table 2. Land purchase and leasing in Kitakyushu Eco-Town (by 2012)

\begin{tabular}{|c|c|c|c|c|}
\hline Zone & Land Owner & Area $\left(m^{2}\right)$ & Land Purchase/Leasing Price & $\begin{array}{c}\text { Land Leasing Price for } \\
\text { Enterprise }\end{array}$ \\
\hline \multirow{3}{*}{$\begin{array}{l}\text { Practical Research } \\
\quad\left(77,000 \mathrm{~m}^{2}\right)\end{array}$} & Local government & 30,435 & 39,000 yen $/ \mathrm{m}^{2}$ & \multirow[t]{2}{*}{40 yen $/ \mathrm{m}^{2} /$ month } \\
\hline & Local government leased from NSC & 7,935 & 78 yen $/ \mathrm{m}^{2} /$ month & \\
\hline & NSC & 38,630 & - & - \\
\hline \multirow{2}{*}{$\begin{array}{l}\text { Industrial Complex } \\
\qquad\left(87,000 \mathrm{~m}^{2}\right)\end{array}$} & Local government & 61,622 & 25,900 yen $/ \mathrm{m}^{2}$ & 33 yen $/ \mathrm{m}^{2} /$ month \\
\hline & NSC & 25,300 & - & - \\
\hline
\end{tabular}

Source: Information provided by Environment Bureau, Kitakyushu City. 


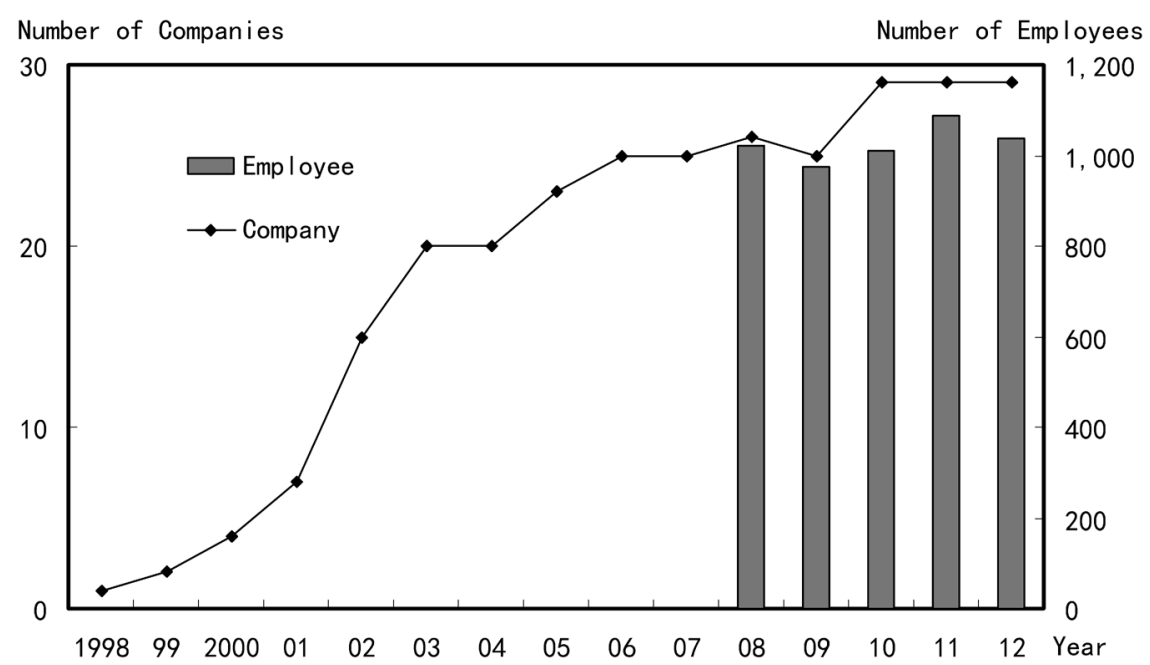

Figure 4. The number of companies and employees in Kitakyushu Eco-Town (1998-2012).

Note: Data of employees in 1998 to 2007 are absent

Source: Information provided by Environment Bureau, Kitakyushu City.

companies in the Eco-Town. In addition, nine companies were established by enterprises located in other cities because of publicity as a result of seminars held in Tokyo and Osaka to introduce Kitakyushu Eco-Town ${ }^{13}$.

Thus, evidence exists suggesting that the local government cooperated with enterprises to promote implementation of the Eco-Town project. The NSC assisted the local government through land provision, infrastructure construction, and new company establishment while the local government supported the NSC through investment, raw material collection, and product advertisements. Moreover, the local government attracted enterprises through providing a support system, holding seminars, and taking advantage of cooperative relationships.

\section{Communication between government and citizens}

In the process of actualizing the Eco-Town project, Kitakyushu City was requested by the central government to construct a PCB treatment facility ${ }^{14}$ in 2001. However, due to PCB's environmental toxicity, the facility was considered hazardous, and the construction encountered opposition from civic organizations and local residents. Eventually, the local government successfully eliminated the opposition and the construction of the PCB treatment facility was completed in 2004.

The local government took a few different approaches to solve this controversial issue. The first approach was information disclosure. One of the main concerns of the opponents of the PCB treatment facility was the safety of the facility because of the highly polluting and dangerous PCBs. Thus, the local government recruited a committee of experts to investigate its safety. More than 100 seminars were held between government officials, experts, and residents to exchange information and opinions. The local government also created a website to facilitate debate, and address the opinions and reactions of residents (Kitakyushu City Association 2003).

The second approach taken by the government was the strategy of scale. The local residents, mainly those of Wakamatsu Ward, raised the issue of the facility's location (Figure 1). They asked the government, "Why Wakamatsu Ward?" and, "Why the Hibikinada Area?" Also, a civic organization called, "Association of Don't Let Hibikinada Area Be a Dump Site for Hazardous Materials," became the main opponent to the facility's construction, questioning the location of the facility. The association submitted eight letters to the local government opposing the PCB treatment facility. The organization's main criticism for a facility located in the Hibikinada Area was that it would have negative effects on the well-being of the residents of the Wakamatsu Ward. In the view of the association, the spread of the Kanemi Rice Oil Disease ${ }^{15}$ in Kitakyushu City in 1968 still haunted the local citizens, and this new facility had the potential to have a similar tragic effect on Kitakyushu citizens (PCB Treatment Safety Investigation Committee 2001). The claims of the association, as either "residents of Wakamatsu Ward" or "Kitakyushu citizens," are focused on civic rights on a local scale.

In contrast, the local government emphasized the extra-local scale. According to its response to local residents and the "Association of Don't Let Hibikinada Area Be a Dump Site for Hazardous Materials," the local government argued that the location was appropriate because the conditions of the Hibikinada Area were appropriate and, more importantly, the PCB treatment facility could be integrated into the development of the Eco-Town proj- 


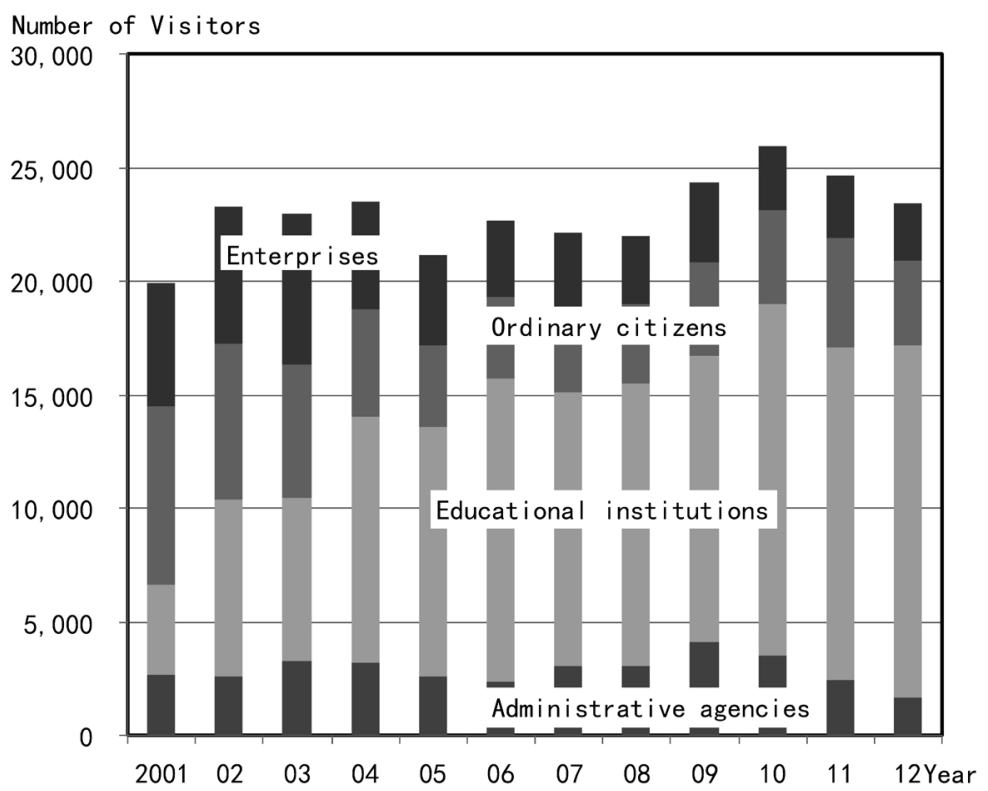

Figure 5. Eco-Town visitors (2001-2012). Source: Information provided by Environment Bureau, Kitakyushu City.

ect. The construction of the facility was crucial for the project to improve the environment, which was also expected to promote the environmental industry of Kitakyushu City and international environmental cooperation (PCB Treatment Safety Investigation Committee 2001). Therefore, associated with the environmental issues on a global scale and with the Eco-Town project on a national scale, the claims of the local government "jumped" to the extra-local scale whereas the opposition of the citizens and civic organizations had been left behind on the local scale $^{16}$

The third approach was citizen participation. Although the local government tried to exchange information with local residents and civic organizations, concerns on the safety of the PCB treatment facility remained among citizens. Therefore, the government set up a PCB treatment monitoring committee, including experts and citizens, to monitor the safety of the facility. After visiting the PCB treatment facility, several comments in support of the facility, such as, "The disposal of PCBs is important to global environmental protection and it is essential not to leave a negative legacy to the next generation," and, "It can be seen that the processing process is strictly controlled," and "If Kitakyushu City cannot control this kind of facility, nowhere can," were made by the citizens who participated in the committee (PCB Treatment Monitor Committee 2005).

In addition, in order to promote citizen participation, the local government constructed an Eco-Town center, where displays from the recycling plant and research facility in the Eco-Town were exhibited. As seen in Figure
5, a large proportion of the visitors came from educational institutions. The Eco-Town project was introduced in elementary and junior high school textbooks in 2002, and the number of students who have taken study tours to Eco-Towns has increased rapidly since then. After students, ordinary citizens are the second-largest proportion of visitors. More than 56,000 ordinary citizens visited Eco-Town during the period from 2001 to 2012.

Thus, through approaches of information disclosure, strategy of scale, and citizen participation, the local government eliminated distrust and active opposition by citizens, resolved the disagreement, and promoted the public understanding of the Eco-Town project.

\section{International Environmental Cooperation}

Through the experience of overcoming severe industrial pollution, Kitakyushu City recognizes that local action can impact on environmental issues on the global scale, and the government has decided to make contributions to local sustainable development in developing countries in Asia and other regions since the 1980s. The city has been dispatching environmental experts to developing countries, and at the same time, it has been accepting trainees from developing countries. In addition, Kitakyushu City has cooperated with Dalian, a friendship city in China, to improve its environmental administration, environmental monitoring, and sewage treatment since 1994.

Since the 2000s, Kitakyushu City began to assist cities in China, such as Tianjin, Dalian, and Qingdao, to construct Eco-Towns. Therefore, the Eco-Town concept has 
moved up to the transnational scale along with the development of international environmental cooperation.

An annual conference, aiming to promote the economic development of the region surrounding the Yellow Sea, has been held for Kitakyushu City and nine cities in China and South Korea since 1996. During the conference in 2002, administrative officers of Qingdao and Tianjin City visited Kitakyushu Eco-Town and showed considerable interest in developing an environmental industry. They requested Kitakyushu City to help them develop environmental industries in their cities. In addition, with rapid urbanization and industrialization, China is facing various environmental challenges. China's central government has started paying attention to the role of Eco-Town projects in creating a recycling-oriented economy. In 2006, an agreement on environmental operations was reached between Japan and China in which Kitaky- ushu City was appointed to assist in Eco-Town construction in China (METI and Kitakyushu City 2012).

In the process of implementing China's Eco-Town projects, Kitakyushu City cooperated with the partner cities by making a master plan, including suggestions on recycling schemes from both the technical and political point of view. They also discussed the business potential for Japanese enterprises in China, and provided a chance for Chinese administrative agencies and enterprises to visit Japan (Table 3). Having the experience of relocating the automobile dismantling industry into the Eco-Town, Kitakyushu City was able to suggest that the local government of Dalian City should consolidate the existing industries. In addition, through holding seminars between Japanese and Chinese enterprises, Kitakyushu City promoted the marketability of enterprises in China's EcoTowns ${ }^{17}$.

Table 3. Environmental cooperation with China's Eco-Towns

\begin{tabular}{|c|c|c|c|}
\hline \multirow{2}{*}{ Period } & Qingdao & Tianjin & Dalian \\
\hline & 2007-2008 & 2008-2009 & 2009-2011 \\
\hline $\begin{array}{l}\text { Recycling } \\
\text { Industry }\end{array}$ & $\begin{array}{l}\text { Home appliances, Automobile, Tires, } \\
\text { Hazardous waste }\end{array}$ & $\begin{array}{l}\text { Home appliances, Automobile, Imported } \\
\text { waste, PET bottles }\end{array}$ & $\begin{array}{l}\text { Home appliances, Automobile, Tires, } \\
\text { Hazardous waste, PET bottles, Waste } \\
\text { plastic, Scrap metal }\end{array}$ \\
\hline Activities & $\begin{array}{l}\text { - Master plan revision support } \\
\text { - Research on home appliance recycling } \\
\text { industry } \\
\text { - Japan-China Recycling City Forum } \\
\text { - Visiting Japan }\end{array}$ & $\begin{array}{l}\text { - Master plan revision support } \\
\text { - Research on automobile recycling } \\
\text { industry } \\
\text { - Business meeting } \\
\cdot \text { Visiting Japan } \\
\text { - Human resource training }\end{array}$ & $\begin{array}{l}\text { - Master plan support } \\
\text { Seminars and business meetings } \\
\text { - Visiting Japan } \\
\text { - Implementation plan support } \\
\text { - Application of existing know-how and } \\
\text { technology in Eco-Town construction }\end{array}$ \\
\hline
\end{tabular}

Source: METI and Kitakyushu City 2012.

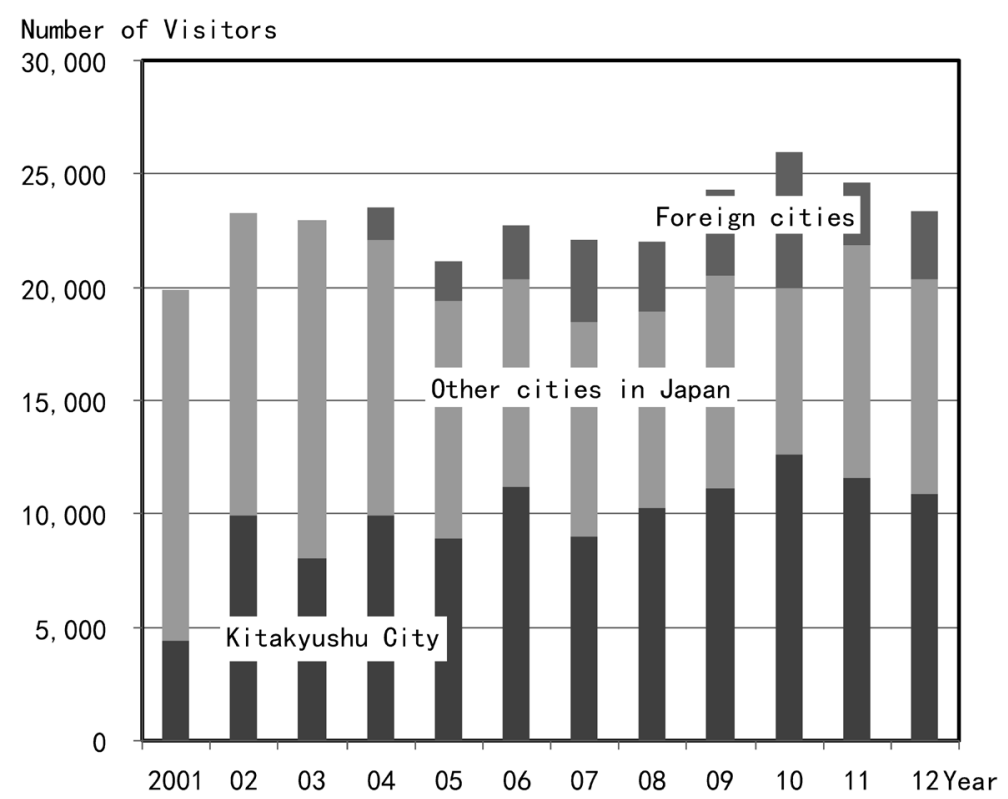

Figure 6. The regional origins of Eco-Town visitors (2001-2012).

Note: From 2001 to 2003, the number of visitors from foreign cities was included in the number of visitors from other cities in Japan.

Source: Information provided by the Environment Bureau, Kitakyushu City. 
At the same time, local enterprises have actively engaged in international environmental cooperation. Kitakyushu International Techno-Cooperative Association (KITA), established by local industrial organizations and the local government, has been providing training programs for trainees of foreign Eco-towns, and dispatching experts to provide guidance and know-how on environmental protection and industrial technology. More than 200 local enterprises and administrative institutions in Kitakyushu City support the KITA.

Thus, through contacting actors in other countries and through international cooperation, the concept of Kitakyushu Eco-Town has spread to the transnational scale. Moreover, the proportion of foreign visitors to Kitakyushu Eco-Town was maintained at around 10\% (Figure 6). According to this percentage, it can also be indicated that Kitakyushu Eco-Town concept has successfully jumped to a global scale.

\section{Conclusions}

Taking the Eco-Town project of Kitakyushu City as a case study, this article examined the policy-making process and how "scale" was used as a local government strategy to gain a consensus among various actors. When experts proposed the scheme to develop a recycling scheme, the local government and enterprises were uncertain about the business potential and consequently did not immediately support it. Moreover, considering the negative effects of the recycling industry, a civic organization opposed the scheme as it was concerned about potential protests by residents. Initially, the local government was not able to resolve the differences in recycling industry development among the actors effectively and the scheme was abandoned.

By adapting to the changing times, the recycling scheme was reintroduced as part of a plan of developing an environmental industry. In other words, local industry development was integrated into global environmental issues. "Jumping scale" was used as a method of supporting the local government's claims. Moreover, the local government contacted actors on a national scale who possessed more power to execute. Subsidized by the MITI, the local recycling scheme was transformed into a national Eco-Town project. "Jumping scale" occurred in the spatial reach of influence of the local government.

In the context of developing the environmental industry and the Eco-Town project, the local government attempted to coordinate the actors participating in the policy-making process. Using research conducted by experts, the local government held a series of seminars to research environmental industry along with enterprises. The NSC and the local government worked together in the process of land transfer, infrastructure construction, and enterprise attraction. Through providing support policies and building relationships with administrative agencies and enterprises, the local government was able to attract enterprises to the Eco-Town. Facing opposition, the local government actively communicated with local residents and civic organizations by approaches of information disclosure, the strategy of scale, and citizen participation.

Furthermore, through connections with Chinese cities and international environmental cooperation, the local government assisted in the establishment of Eco-Towns in China. Ultimately, the Eco-Town concept spread to the transnational scale, and the spatial reach of influence of the local government and the Eco-Town project was broadened once again.

Therefore, by using a scale strategy, the local government spread local policy to the national and transnational scale, and the local government stretched its influence by "jumping scale." The local government also fostered partnerships and cooperation among actors through the strategy of scale. A consensus among the local government, enterprises and the citizens was established by transforming the recycling industry, which was initially seen as a waste disposal industry with negative effects, into an environmental industry, which is critical on a global scale. In other words, on the one hand, the local government realized the scale change and stretched the influence of the Eco-town project through contacting with actors beyond the local scale. On the other hand, the local government realized the Eco-town project and resolved the disagreement through associating its concept with issues on an extra-local scale. In this sense, the strategy of scale helps in coordinating the policy-making process and in expanding the influence of policy.

\section{Acknowledgements}

This article is part of a $\mathrm{PhD}$ thesis submitted to Kyushu University. An abbreviated version of this was presented at the 8th Japan-Korea-China Joint Conference on Geography at Kyushu University in August 2013. The author wishes to thank Professor Akihiko Takagi, members of the Department of Geography at Kyushu University, and anonymous reviewers for their very helpful comments and criticisms. Thanks are also due to all those who gave the author valuable information during interviews and fieldwork. 


\section{Notes}

1. In 2001 in Japan, the Ministry of International Trade and Industry (MITI) was merged with agencies from other ministries related to economic activities, and the Ministry of Economy, Trade and Industry (METI) was created.

2. In this article, "Kitakyushu City" refers to the city as a geographical notion. "Local government" refers to the administrative organization.

3. The five cities became wards of Kitakyushu City after the merger. Now Kitakyushu City has seven wards after Kokura Ward was divided into Kokurakita and Kokuraminami Ward and Yahata Ward was divided into Yahatahigasi and Yahatanishi Ward in 1974.

4. Its predecessor is the government-owned Yahata ironworks, which was constructed in 1896 in order to meet the increasing demand of burgeoning shipbuilding, railway construction, and armaments industries in Japan.

5. The largest public university in Kyushu region, which is one of the top research institutions in Japan.

6. Interview with a professor of the University of Kitakyushu, who was involved in the research group at that time.

7. Interview with one of the officers in charge of the Eco-Town project in Kitakyushu City.

8. A private university in Fukuoka City, Japan.

9. One of the companies, West Japan PET Bottle Recycle, which was established in 1997, uses several processes to recycle used PET bottles and produce clear PET resin, which is then sold as raw material for textiles or containers.

10. Although the price of leasing land was the market price, it can reduce the financial burden of the enterprises compared with the land purchase.

11. ELV means "End of Life Vehicles." This is a company engaged in dismantling automobiles, established by 7 enterprises located in Kitakyushu City in 2002.

12. See note 7 above.

13. Interviews with two officers of Environmental Bureau, Kitakyushu City.

14. To dispose PCB (Polychlorinated Biphenyl) containing wastes of 17 prefectures located to the west of Okayama Prefecture.

15. Kanemi Rice Oil Disease was a mass poisoning by PCBs which occurred in Kitakyushu City in 1968. Rice oil was contaminated with PCBs by accident and then sold to farmers for use as a feed supplement and to consumers for use in cooking. About 14,000 people who had consumed the contaminated rice oil were affected in Japan. Common symptoms included dermal and ocular lesions, irregular menstrual cycles and a lowered immune response.

16. Whether the citizens and civic organizations have extended their opposition to the extra-local scale, will be investigated in the future.

17. Interview with an officer of Environment Bureau of Kitakyushu City, who was involved in the international cooperation efforts.

\section{References}

Bayirbag, M. K. 2010. Local entrepreneurialism and state rescaling in Turkey. Urban Studies 47: 363-385.

Brown, J. C. and Purcell, M. 2005. There is nothing inherent about scale: Political ecology, the local trap, and the politics of development in the Brazilian Amazon. Geoforum 36: 607-624.

Editing Group of Pollution Control History 1998. Kitakyushu kogai taisakushi. Kitakyushu: Kitakyushu City. (J)

Hibikinada Area Development Plan Committee 1992. Hibikinada chiku kaihatsu kihon koso. Fukuoka: Kyushu Economic Research Center. (J)

Hibikinada Area Development Promotion Committee 1996. Hibikinada kaihatsu kihon Keikaku. Kitakyushu: Kitakyushu City. (J)

Hibikinada Area Development Promotion Council 2003. Hibikinada chiku tochi kaihatsu kihon puran. Kitakyushu: Kitakyushu City. (J)

Kitakyushu City Association 2003. Eco-town e no michisuji. Kitakyushu: KCA. (J)

Kitakyushu City Government 2011. Kitakyushu choki jikeiretsu tokei(kogyo). www.city.kitakyushu.lg.jp/soumu/file_0351.html (last accessed 2 July 2013). (J)

Kyushu Economic Research Center 2003. Chiiki no jiritsuteki hatten ni mukete. Fukuoka: KERC. (J)

Lai, C. 2013. Saving Japan town, serving the people: The scalar politics of the Asian American movement. Environment and Planning. D, Society \& Space 31: 467-484.

Martin, D., Mccann, E. and Purcell, M. 2003. Space, scale, governance, and representation: Contemporary geographical perspectives on urban politics and policy. Journal of Urban Affairs 25: $113-121$.

Matsunaga, H. 2004. Agglomeration of the heavy and chemical industries and the generation of the environmental industries. Annals of the Japan Association of Economic Geographers 50: 325-340. (JE)

Merk, J. 2009. Jumping scale and bridging space in the era of corporate social responsibility: Cross-border labour struggles in the global garment industry. Third World Quarterly 30: 599-615.

METI and Kitakyushu City 2012. Chugoku ni okeru eco-town donyu gaidorain. Tokyo: METI. (J)

Molle, F. and Mamanpoush, A. 2012. Scale, governance and the management of river basins: A case study from Central Iran. Geoforum 43: 285-294.

Nakamura, K. 2001. Zero-emisshon to eco-town keikaku. Kankyo to Kogai 31: 23-30. (J)

Okamura, R. 2004. Jidosha risaikuru to eco-town jigyo. In Jidosha Risaikuru, ed. K. Takeuchi, 181-225, Tokyo: Toyo Keizai. (J)

PCB Treatment Safety Investigation Committee 2001. PCB Shori Anzensei Kento Iinkai Hokokusho. Kitakyushu: Kitakyushu City. (J)

PCB Treatment Monitor Committee 2005. PCB Shori Kanshi Iinkai Dayori. www.city.kitakyushu.lg.jp/business/Menu 03_0174. html (last accessed 19 December 2013). (J)

Samuta, H. 2003. Kawasaki eco-town no chiikiteki kankyo keizai shisutemu. Economic Review of Kanazawa University 23: 271302. (J)

Smith, M. C. and Kurtz, H. 2003. Community gardens and politics of scale in New York City. Geographical Review 93: 193-212.

Smith, N. 1992. Geography, difference and the politics of scale. In Postmodernism and the Social Sciences, ed. J. Doherty, E. Graham and M. Malek, 57-59, London: Macmillan Academic and Professional.

Swyngedouw, E. 1997. Excluding the other: The production of scale and scaled politics. In Geographies of Economies, ed. R. Lee and J. Wills, 167-176, London: Arnold.

Togawa, K. 2000. Jomyaku sangyo no ritchi to sono ikusei seisaku. Economic Review of Kyushu University 67: 141-181. (J) 
Togawa, K. 2001. Regional polices of waste and recycling management in today's Japanese economy. Association of Economic Geographers 47: 258-271. (JE)

Tretter, E. 2008. Scales, regimes, and the urban governance of Glasgow. Journal of Urban Affairs 30: 87-102.

Yamamoto, K., Nishizawa, E. and Masuda, T. 2006. Philosophy and realities of eco town projects in Japan : A case study of Omuta eco town. Hosei University Economic Review 73: 741-792. (JE)

Yamazaki, T., Takagi, A., Kitagawa, S. and Kagawa, Y. 2012. Reemerging political geography in Japan. Japanese Journal of Human Geography 64: 544-566.

(J) written in Japanese

(JE) written in Japanese with English abstract 